\title{
前塩素処理した緩速ろ過池モデルの 砂層における抑留物質の深度分布
}

\section{Depth Distribution of Suspended Matter in the Sand Layer of Slow Sand Filter Model Treated by Chlorination}

\author{
山本満寿夫、山下昌輝、中本信忠
}

\author{
信州大学繊維学部応用生物科学科/ ₹ 386-8567 上田市常田3-15-1 \\ MASUO YAMAMOTO, MASAKI YAMASHITA, and NOBUTADA NAKAMOTO \\ Department of Applied Biology, Faculty of Textile Science and Technology, Shinshu University \\ /3-15-1, Tokita, Ueda, Nagano 386-8567, Japan
}

\begin{abstract}
The research was carried out to appreciate a slow sand filtration treatment by an investigation of suspended matter distribution in sand beds. The chlorination treatment was given to sand beds. The core-sampler to take suspended matter was inserted in slow sand filter model beds during the filter operation. The following results were obtained.

Normalized head loss value was increased at a chlorination treatment model than at a nonchlorination model (control model) after about 35 days of filter run. From the depth distribution of the suspended solid (SS), a model with chlorination treatment retained large amount of suspended matter than a model treated by non-chlorination. And suspended matter was mainly retained at the extremely thin layer at the sand column of a control model.

Small animals increased in the upper sand layer of a control, but were not existed in a model chlorination treatment.

Measurement of particles in filtered water by a particle counter were decreased at a control model accompany with filter run.
\end{abstract}

Key words : slow sand filter, chlorination treatment model, suspended matter distribution

\section{1.はじめに}

緩速ろ過処理法は砂による篩い分け・吸着という物理 的作用と共に、砂層表面と砂層内に繁殖した微小動物、 バクテリア等の従属栄養生物により水中の不純物を捕捉 し無機化する生物作用が重要な役割を担う浄化方法 ${ }^{1-6)}$ である。

東京都水道局砧上浄水所 ${ }^{7}$ では、万過池内で鞭毛藻類 や糸状藻類の繁殖が著しかった。鞭毛藻類が繁殖した場 合しばしばろ過水中に藻類が漏出し、万過水の濁度を上
昇させることがあっだ。そこでろ過池内へ次亜塩素酸ナ トリウムを撒布して藻類繁殖を抑制した時期があった。 また、大阪市水道局等の試験 ${ }^{8-9}$ でも、万過池内で繁殖 する藻類を防止する目的で前塩素処理の実験が行われた。 長野県上田市水道局 ${ }^{10-111}$ においても1960年代まで前塩 素処理をして䋸速ろ過処理をしていた。その結果、水道 水に異臭味が生じて問題になった。その後のトリハロメ 夕ン騒ぎで前塩素処理を中止したら異臭味騒ぎがなくな った。また、沖縄県宮古島水道企業団の袖山浄水場 ${ }^{11}$ で は1959年の創設当時から前塩素処理をして緩速ろ過処理 
をしてきたが、最近、前塩素処理を中止したら水の味が 良くなったと評判になった。前塩素処理が砂層内の生物 の働きを抑制するが、緩速ろ過池がろ過閉塞し易くなる ことについては検討がされていない。

そこで、本実験では河川表流水を取水する上田市水道 局染屋浄水場内に緩速ろ過池モデルを設置して、前塩素 処理をしたときのろ過池砂層における抑留物質の深度分 布について検討を行った。

\section{2. 方 法}

\section{1 万過池モデルおよび実験期間}

実験は、家庭用のプラスチック浴槽を用いたろ過池モ デルに、染屋浄水場の沈殿水を引き入れて行った( Fig. 1)。乃過池モデルは塩素添加区と塩素添加しない対 照区の二つのモデルを設置した。ろ過面積は $0.42 \mathrm{~m}$ で、 塩ビ管を二つ割りにした中にろ過砂を詰めた砂層カラ ム ${ }^{13 .}$ (直径 $5 \mathrm{~cm}$ 、長さ $15 \mathrm{~cm}$ ) をモデル内に設置した。

なお、使用したろ過砂は有効径 $0.32 \sim 0.36 \mathrm{~mm}$ で標準 万砂（粒径0.30 0.45 $\mathrm{mm}^{1+}$ ) の範囲内である。二つの モデルに各 8 本から10本の砂層カラムを $10 \mathrm{~cm}$ 間隔で埋 込んで、ろ過継続中にほほ10日間隔で 2 本ずつ砂層カラ ムを取り上げて、砂層内の抑留物質と微小動物の深度分 布について調査を行った。調查は塩素処理をしないろ過 池を対照モデルとし、次亜塩素酸ナトリウムで前塩素処 理をしたろ過池を前塩素処理モデルとした。添加した塩 素濃度は谷本 ${ }^{8:}$ 、近藤 ${ }^{15}$ らに準拠して未ろ水の濃度が $0.5 \mathrm{mg} / l$ 前後になるようにした。調査は1997年 9 月10日 〜10月24日の 45 日間に行った。

\section{2 分析方法}

採取した塩ビ管中の砂層は深度別に切断した後に既 報 ${ }^{12-14:}$ と同じ処理を行って浮遊物質 (suspended solid、 以下 SS と略す)、全有機炭素 (total organic carbon、 以下 TOC と略す)、クロロフィル (chlorophyll $a$ 、以 下 Chl. $a$ と略す) を分析した。実験はダブルでおこな い2 本の值を平均した。

砂層内の微小動物についてはユスリカ類、貧毛類、線 虫類の個体数を計数した。また、両池の浄化能をみるた めに、微粒子カウンター ${ }^{16}$ により粒子径 $2 \sim<10 \mu \mathrm{m}$ の 微粒子数を測定した。

\section{3. 結 果}

\section{1 万過池流入懸濁物質量と標準化損失水頭}

調査期間中の流入水濁度を万過池使用日数で Fig. 2 に示した。調查開始から9 日間ほど悪天候が続き、着水 井で濁度12度を越えると凝集剤（PAC）が注入された ためにモデルへの流入濁度は極端に低かった。その後、 濁度は平均 4 度前後で推移した。

また、標準化損失水頭 ${ }^{17}$ (Normalized Head Loss、 以下 NHL と略す）と使用日数の関倸について Fig. 3 に 示した。標準化損失水頭とは、英国で用いられている標 準ろ過速度の $20 \mathrm{~cm} / \mathrm{h}(4.8 \mathrm{~m} / \mathrm{d})$ でろ過した場合の損失 水頭に換算して表わした数值である。その結果、ろ過池 使用初期、悪天候が続いたために対照モデルの藻類の発 育が遅れた。ろ過池使用20日間くらいまでは、対照モデ ルに比べて前塩素処理モデルの方がやや NHL が高く推 移した。25日以降になると対照モデルよりも前塩素処理

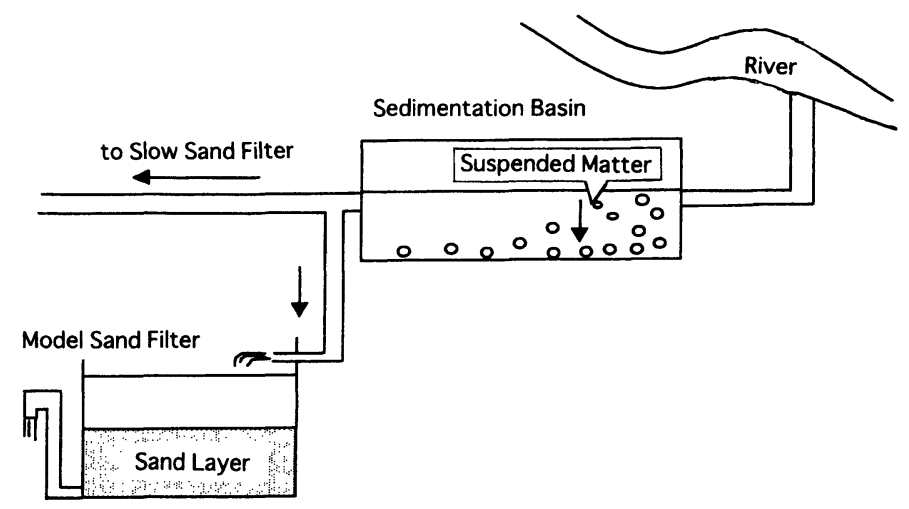

Fig. 1 The flow of the water from the river 


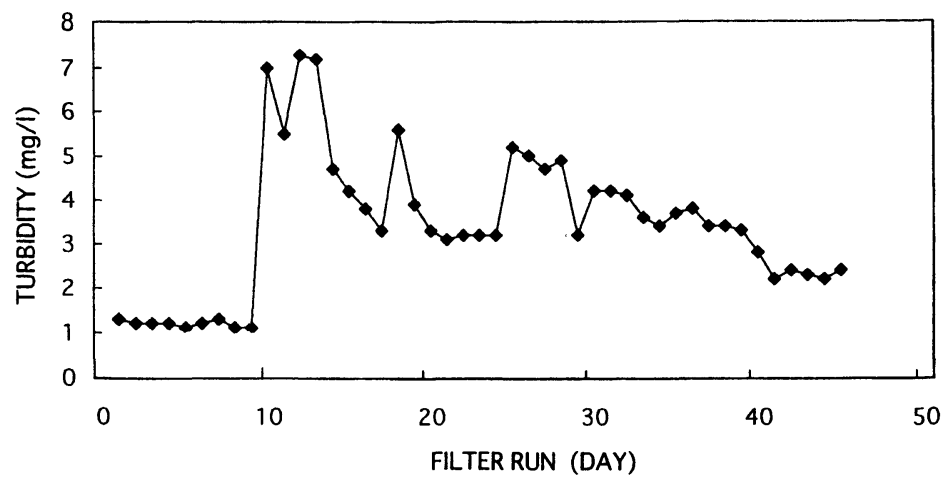

Fig. 2 Turbidity change in inflow water of slow sand filter models during the filter run (days) from September 10 to October 24 in 1997

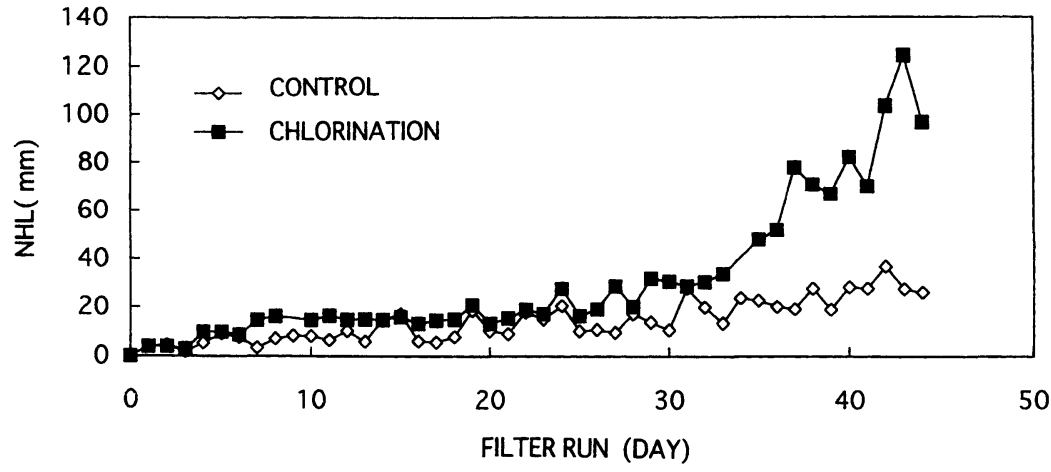

Fig. 3 Normalized head loss change (NHL) of slow sand filters with non-chlorination model (white square) and a pre-chlorination model plant (black square) during filter run from September 10 to October 24

モデルの NHL が明らかに高くなる傾向を示し、43日目 で約 $130 \mathrm{~mm}$ 近くまで上昇し、対照モデルとの差が 5 6 倍にもなった。このことから、前塩素処理モデルの方 が対照モデルに比べてろ過閉塞し易いことを示していた。

\section{2 前塩素好理モデルと対照モデルのSS の深度分布}

乾燥砂（g）当たりのSS の深度分布を Fig. 4-1に示 した。SSは前塩素処理モデル、対照モデル共に上層か ら約 $2 \sim 3 \mathrm{~cm}$ 深の間に值が減少した。砂層表層の抑留 量はろ過池使用初期は両者あまり差はみられないが、30 日目になると表層から約 $2 \mathrm{~cm}$ 深間に前塩素処理モデル の方が多量の䋰濁物質が抑留された。表層における抑留 量は、前塩素処理区で平均 $13.9 \mathrm{mg} / \mathrm{g}$ であるのに対して 対照区では $8.07 \mathrm{mg} / \mathrm{g}$ であった。45日目でも前塩素処理 区の平均が $19.4 \mathrm{mg} / \mathrm{g}$ 、対照区が $15.8 \mathrm{mg} / \mathrm{g}$ と差が明確で あった。しかし、約 $2 \mathrm{~cm}$ 以深については両区共に平均 $3 \mathrm{mg} / \mathrm{g}$ 前後で顕著な差がなかった。以上、前塩素処理
区では30日目から45日目の間に砂層上部の抑留量が対照 区に比べて増加しているが、同時にNHL が上昇した時 期とも一致した。

\section{3 前塩素処理モデルと対照モデルの TOC の深度分布}

TOCの深度分布をFig. 4-2 に示した。TOC は全般 にSS と類似した深度分布を示し、ろ過池使用後半にな ると上層から約 $2 \sim 3 \mathrm{~cm}$ 深間の減少が顕著であった。 砂層上部の0 0.5cm 層の值を30日目の前塩素処理モデ ル、対照モデルで比較すると 1.7 倍ほど前塩素処理モデ ルの方が TOC 量が多かったが、45日目には前塩素処理 モデルと対照モデルの比が0.7倍とやや対照モデルの方 が高くなった。

3. 4 前塩素処理モデルと対照モデルのChl. $a$ の深度分布 砂層内に侵入し抑留されている藻類量を Chl. $a$ を指 標として Fig. 4-3に示した。対照モデルでは、ろ過池 


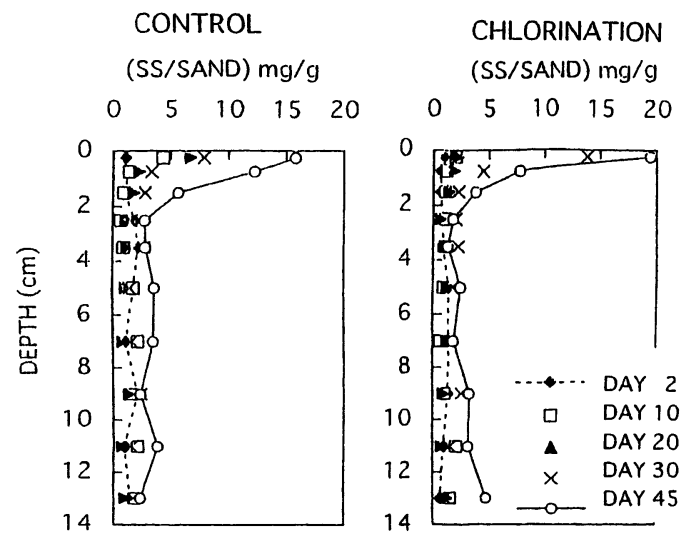

Fig. 4-1

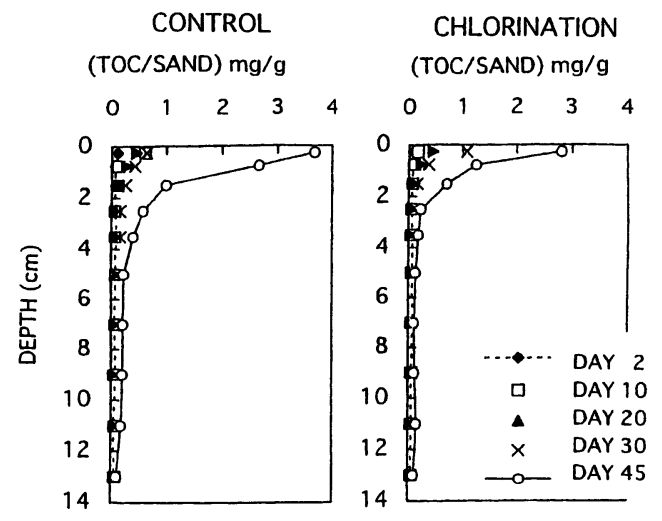

Fig. 4-2

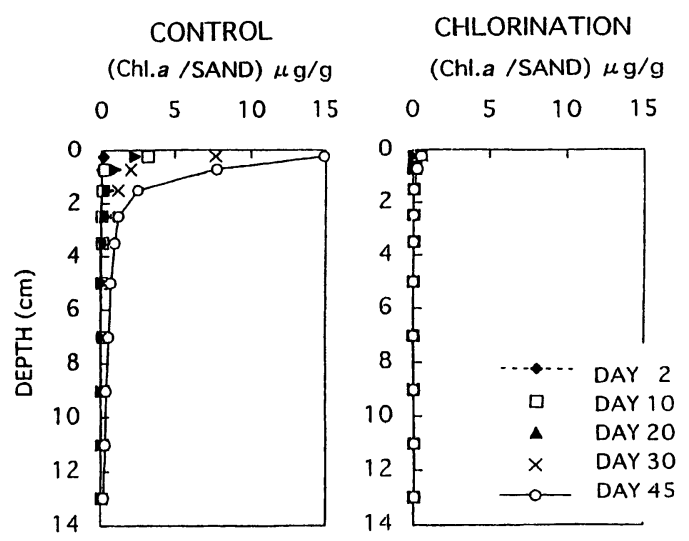

Fig. 4-3

Fig. 4 The depth distribution of the Suspended Solid (SS) per dry SAND

(Fig. 4-1) and Total Organic Carbon(TOC/SAND (Fig. 4-2), Chlorophyll a(Chl .a/SAND

(Fig.4-3) in upper sand columns on different days at slow sand filters with non-chlorination model and a pre-chlorination model plant from September 10 to October 24
使用的20日目に砂層上に藻類が繁殖しはじめ藻類被膜が 形成された。その後 30 日目、45日目には砂層上部 $2 \mathrm{~cm}$ くらいまでChl. $a$ が抑留されていた。それに対して前 塩素処理モデルでは流入水に塩素添加されたことで藻類 はほとんど繁殖せず、砂層内にもChl. aはほとんど抑 留されなかった。

\section{5 前塩素処理モデルと対照モデルの微小動物の深度 別個体数}

両ろ過池モデル砂層内の微小動物（ユスリカ類・貧毛 類・線虫類) は前塩素処理モデルでは使用開始から45日 目まで出現しなかった。一方、対照モデルも20日目まで 微小動物は出現しなかったが、30日目に貧毛類が出現し はじめ、少数であるがユスリカ類も砂層上層で観察され た。45日目にはユスリカ類・貧毛類の他に線虫類もみら れた (Table 1)。これら微小動物は砂層上部 $0 \sim 3 \mathrm{~cm}$ の間に多く生息し、特に貧毛類の個体数が大幅に増加し、 砂層0.5 $1.0 \mathrm{~cm}$ 層では $6.71 匹 / \mathrm{cm}^{3}$ が観察された。この ことは、餌となる懸濁有機物質が砂層上部に多く抑留さ れているために、それを摂食する微小動物が多く存在し たものと考えられた。

\section{6 前塩素処理モデルと対照モデルのろ過水中の微粒子数}

両乃過池モデルの浄化能をみるために、微粒子カウン ターを使用して、ろ過池使用日数とろ過水中の微粒子の 関係(Fig. 5) を調査した。その結果、対照モデルのろ過 水中の $2 \sim<3 \mu \mathrm{m}$ 間の微粒子数は $50 \sim 180 \mathrm{n} / \mathrm{ml}$ 、それ に対して前塩素処理モデルは $50 \sim 250 \mathrm{n} / \mathrm{m} l$ で、微粒子数 の幅が詨照モデルよりもやや大きかった。また、 $3 \propto 5$ $\mu \mathrm{m}$ 間の微粒子数は対照モデルで $50 \sim 150 \mathrm{n} / \mathrm{ml}$ 、前塩素

Table 1 Some animals number in upper sand columns of control model (without chlorination) on the 45 days of filter run

\begin{tabular}{cccc}
\hline layer $(\mathrm{cm})$ & $\begin{array}{c}\text { Chironomus } \\
\text { larva }\end{array}$ & Oligochaeta & Nematoda \\
\hline $0-0.25$ & 0.26 & 3.3 & 1.45 \\
$0.25-0.75$ & 0 & 6.71 & 0.91 \\
$0.75-1.5$ & 0 & 3.59 & 0.07 \\
$1.5-2.0$ & 0 & 1.56 & 0.14 \\
$2.0-2.5$ & 0 & 0.2 & 0 \\
$2.5-5.0$ & 0 & 0.17 & 0 \\
$5.0-7.0$ & 0 & 0.06 & 0 \\
$7.0-9.0$ & 0 & 0 & 0 \\
$9.0-11.0$ & 0 & 0 & 0 \\
$11.0-13.0$ & 0 & 0 & 0 \\
\hline & & & $\left(\mathrm{n} / \mathrm{cm}^{3}\right)$
\end{tabular}



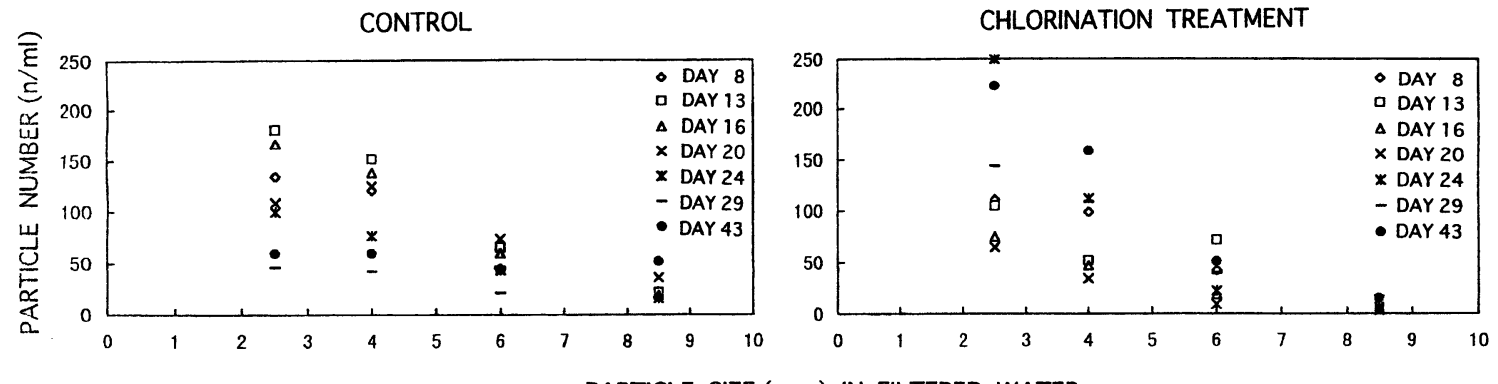

PARTICLE SIZE $(\mu \mathrm{m})$ IN FILTERED WATER

Fig. 5 The relation between particle numbers per $\mathrm{ml}$ and particle size in filtered water with non-chlorination model and a pre-chlorination model plant. Particle numbers per $\mathrm{ml}$ are counted in the following size fraction, $2 \sim<3 \mu \mathrm{m}, 3 \sim<5 \mu \mathrm{m}, 5 \sim<7 \mu \mathrm{m}$ and $7 \sim$ $<10 \mu \mathrm{m}$ in diameter Vertical marks indicate each sampling day of filter run

処理モデルでは30～160n/m lでやはり処理モデルの方が やや微粒子数の幅が大きかった。次の $5 \sim<7 \mu \mathrm{m}$ 間の 微粒子数は両者とも約 $70 \mathrm{n} / \mathrm{m} l$ 以下で大差はなかったが、 7 〜 $10 \mu \mathrm{m}$ 間では対照モデルの方がやや微粒子数の幅 が大きかった。一方、ろ過池使用日数と微粒子数につい てみると、対照モデルでは使用日数が長くなると微粒子 数が減少するのに対して、前塩素処理モデルでは逆に多 くなる傾向がみられた。このことから、浄化能は前塩素 処理モデルよりも対照モデルの方が良いことが示唆され た。

\section{4. 考察}

ろ過池を長期間継続使用していると対照モデルに比べ て前塩素処理モデルの標準化損失水頭 (NHL) が上昇 した。その理由の一つとして、ろ過池使用後半からの砂 層表層の懸濁物質（SS）の堆積量の違いが考えられた。 前塩素処理モデルに比べて藻類の生育が旺盛な対照モ デルは、光合成によって生産される酸素の気泡と共に糸 状藻類被膜に捕捉された流入懸濁物質が剥離浮上して越 流管から流出する。一方、藻類が生育しにくい前塩素処 理モデルは、対照モデルのように流入懸濁物質を捕捉す る糸状藻類の剥離浮上がないから、流入懸濁物質は砂層 表層に堆積し易くなる。これはろ過池を遮光したときの 眯濁物質の堆積機構 た。しかし、ろ過池使用43日目の前塩素処理モデルと対 照モデルの NHLの差が 4 〜 倍になるのに、対照モデ ルでは依然として NHL 值が $25 \mathrm{~mm}$ 前後で低く維持され ており、NHL 值が上昇しない原因があるのではないか と考えた。
前塩素処理モデルは、砂層中にほとんど藻類の抑留が ないばかりか、微小動物もほとんどみられなかった。そ れに対して対照モデルは、ろ過継続30日くらいから微小 動物が増えはじめ、45日目には砂層上部の0〜 $5 \mathrm{~cm}$ 層 で数多く生息しているのがみられた。対照モデルはこの 微小動物が活動することにより砂層中に水道（路）がで きて、ろ過閉塞を遅延していることが示唆された。その 結果、万過水中の $2 \sim<3 \mu \mathrm{m}$ 間の細かな微粒子数が前 塩素処理モデルに比べて半分以下と少なく、高い浄化能 が維持されていることを示した。物理的にはろ過抵抗の 高い前塩素処理モデルのろ過水の方が微粒子数が少ない はずであるが、結果が逆になったのは、対照モデルでは 微小動物（繊毛虫など）が微粒子を捕捉しているこ と ${ }^{16} 17$ が推測された。

以上、緩速乃過池の前塩素処理は、藻類の発達と微小 動物の活動や細菌を抑制することになり、生物作用が抑 制された結果、万過閉塞しやすい状況となってろ過水に も悪影響を与えることが判明した。このことから、緩速 万過処理法は生物が重要な役割を担っていることが再認 識され、万過池管理には生物作用を阻害しないような配 慮が必要であると考えられた。

\section{5. 結論}

前塩素処理した緩速ろ過池モデルと前塩素処理しない 対照モデルの砂層に、ろ過砂を詰めた塩ビ管を挿入し、 ろ過継続中に取り出して抑留物質の深度分布を調査した。 また、微小動物の深度分布を測定した。その結果以下の ことが明らかになった。

1）万過継続をしていくと、対照モデルに比べて前塩素 
処理モデルの標準化損失水頭（NHL）が上昇した。

2）万過池使用後半、前塩素処理モデルは対照モデルよ りも砂層の極表層における懸濁物質（SS）の抑留量が 多かった。

3 ) 前塩素処理モデルの砂層では藻類量（Chl.a）の抑 留はほとんどなかった。

4 ）対照モデルでは砂層内の微小動物は使用日数が長く なると砂層上部で多くみられたが、前塩素処理モデル ではほとんどみられなかった。

5 ）対照モデルのろ過水中の微粒子数は使用日数が長く なると減少したが、前塩素処理モデルでは反対に多く なった。

謝辞：本研究を行うにあたり浄水場内での実験場所およ び資料を提供していただいた、上出市水道局に感謝いた します。また、微粒子計測器、WATER GRAB SAMPLER, MODEL WGS-267を貸与していただいた川鉄商事株式 会社に感謝いたします。

\section{引用文献}

1) 厚生省環境衛生局水道環境部：水道維持管理指針、 日本水道協会、1-655(1982)

2 ) 厚生省：水道施設設計指針・解説、日本水道協会、 $1-715(1990)$

3 ) 中本信忠：緩速乃過における系状藻類の有用性、水 道協会雑誌、55(3), 19-21(1986)

4 ) 中本信忠, 坂井 正：緩速乃過池における系状珪藻 とその連続培養の重要性、日本水処理生物学会誌、 27 (1)、33-38 (1991)

5 ) 佐藤米司, 福士憲一, 丹保憲仁：緩速乃過の生物化 学的機能一砂乃過の生物化学的機能の見直しに関す 万研究 (1) 水道協会雑誌、61(12)，11-23(1992)

6 ）住友 恒, 赤沢尚文, 奥村充司, 尾崎正明, 山本昌 弘：緩速乃過における生物分解能と定量化とその効 率化の実験一生物分解による上水の高度処理に関す る研究 (2) 一、水道協会雑誌、55(10)，22-29(1986)
7 ) 斎藤 滋, 黑川正博, 岸野 靖, 小山美喜彦：緩速 滤過に於ける遮光による藻類繁殖抑制実験について、 日本水道協会関東支部水質研究発表会概要集、24$26(1994)$

8 ）谷本 清：大阪市上水道緩速滤過に於ける濾過前塩 素消毒試験成績、水道協会雑誌、29、20-35(1935)

9 ）田中利昭，黑川正博：緩速ろ過池における前塩素間 欠注入による藻類制御、日本水道協会関東地方支部 水質研究発表会概要集、16-18(1990)

10）中本信忠，坂井 正：1973年の上田市水道水の異臭 味問題と前塩素処理と緩速乃過池の藻類被膜の発達、 信州大学環境科学年報、第18巻、69-73(1996)

11）中本信忠：現代に通用する古い技術の緩速ろ過処理 (2)、水、40-15(No.575)、67-73(1998)

12）山本満寿夫，大島 茂，中本信忠：緩速乃過池モデ ルを遮光したときの砂層における抑留物質の深度分 布、日本水処理生物学会誌、35(1)、29-36 (1999)

13）山本満寿夫，中本信忠：冬期の緩速乃過池砂層にお ける抑留物質の深度分布、日本水処理生物学会誌、 33 (3) 、109-116 (1997)

14）山本満寿夫，中本信忠：河川表流水を水源とする緩 速万過池砂層における抑留物質の深度分布、日本水 処理生物学会誌、32(2)、123-129(1996)

15）近藤正義：緩速滤過に於ける原水塩素消毒の爾後生 物相に及ぼす影響、大阪市上水道の生物学的研究、 第 7 篇、水道協会雑誌、34、14-23(1936)

16）山本満寿夫，中本信忠：微粒子カウンターによる水 道水中の微粒子数、日本水処理生物学会誌、34(2)、 61-68(1998)

17）中本信忠，坂井 正：緩速乃過池のろ過閉塞指標之 しての標準化損失水頭と藻類、日本水処理生物学会 誌、28(1)、7-16(1992)

18）上野英世：緩速乃過池の菌類に関する研究（I）緩速乃過池内に拈硝化細菌の分布一水道協会雑 誌、331、55-61 (1962)

19）上野英世：緩速ろ過池の菌類に関する研究（II）緩速万過池内における糸状菌類について一水道協会 雑誌、333、49-54 (1962)

(受付 2000. 2.7) (受理 2000. 3.22) 